\title{
Research on Venture Capital Exit for Science and Technology Innovation Enterprise
}

\author{
Ding Wenhui \\ Guangdong University of Science and Technology 523000
}

\begin{abstract}
Keywords: science and technology innovation enterprise; venture capital exit; exit mode; influence factors; exit strategies
\end{abstract}

\begin{abstract}
Science and technology innovation enterprise is high investment and high risk, the shortage of capital is the key problem to restrict its development, and venture capital exit is the main way to solve this problem. Venture capital exit directly affects the success or failure of venture capital. Venture capital exit way and its influencing factors are based in this paper, to address the problems of current science and technology innovation enterprise venture capital exit, with reference to previous research results, and puts forward the technology innovation enterprise venture capital exit strategy. Specific strategies include: Scientific and technological innovation enterprises listed on the exit is promoted. Cultivating high quality venture capital talents. Special property rights exchange is set up. Venture capital policy support is strengthened. The intermediary institutions of venture capital is cultivated and standardized.
\end{abstract}

Project funding: Research on venture capital in the process of commercialization of Dongguan science and technology innovation enterprises-GKY-2015KYYB-30

Author introduction: Ding Wenhui Male Birthday on May 1970 and birthplace at Xiayi,Henan Lecturer Postgraduate Study on finance and investment 523000 Finance Department, Guangdong University of Science and Technology,No.99, Xihu Road, Nancheng District,Dongguan, Guangdong Guangdong University of Science and Technology。

\section{Introduction}

Scientific and technological innovation enterprises is the core technology and famous brand with independent intellectual property rights, with good management and culture of innovation. Its overall technical level occupies the leading position in the same industry. It has the advantage and ability of sustainable development enterprises in the market competition. The main characteristics of technology innovation enterprise is: Reaching research and development institutionalization in enterprise internal; research and development become one of the core functions of the enterprise; it has completely realized the triune localization of research, production and sale; it has formed a sound mechanism of the interactions of research, production and sale; sustainable income is made through continuous innovation; continuous innovation is the essential characteristic. With the development of economic globalization and the arrival of the era of knowledge economy, science and technology has become the decisive factor of the economic development of all countries, which makes the development of scientific and technological innovation enterprises in the economic development of the role of more prominent [1]. Scientific and technological innovation enterprises have high investment and high risk characteristics, the shortage of funds is a key factor to restrict its development.

Venture capital is a kind of investment behavior that mainly to equity capital to invest in a high growth potential, but at the same time in all aspects of technology and market exist the failure risk of high and new technology industry, and actively participate in the management, in order to promote the combination of finance, industry and scientific research. From the perspective of investment behavior, the venture capital is the capital to invest research and development of the field in bears the risk of failure of new and high technologies and products, in order to promote the 
commercialization and industrialization of achievement of new and high technology as soon as possible. It is an investment process to get high profit from the capital. From the mode of operation, it is the process that the intermediary under the professional of the investment management personnel put venture capital in high technology enterprise with the special potential, is the coordination of the relationship between venture capitalists, technical experts and investors. It is a benefit sharing and risk sharing investment.

Venture capital operation includes four stages, such as financing, selection of investment, operation management and withdrawal. Exit means venture capital institutions in the case of the investment of enterprise development is relatively mature or not to the healthy development, the conversion of the capital will be invested by the form of equity as a form of capital, in order to achieve the link of capital appreciation, avoid or reduce the loss of property [2]. Venture capital exit and the result how to exit, directly affect the success or failure of the whole venture capital. To get out of compensation through the risk of investment, is the main driving force to participate in of risk investment; mature venture enterprise and its stake in the market value fuses the potential market value and business opportunities, making venture capital exit become a section of directly measure the risk of enterprise market value; when the venture capital makes an ideal market return, investors will be more actively involved in the risk of investment, so as to form a good cycle of venture capital investment. As can be seen from the operation mechanism of venture capital, venture capital exit mechanism is an important part of the whole process of risk investment action, is the key to the circulation of risk capital, is the past behavior of the end, and is the starting point of the new behavior. At present, China's scientific and technological innovation venture capital exit mechanism has not been fully established, there are many problems, especially the risk of capital exit narrow channels, hinder the development of venture capital. Through this research, we establish and perfect the venture capital exit mechanism of China's scientific and technological innovation enterprises, widen the exit channels of venture capital, and serve the healthy development of China's economy and technology innovation enterprises.

\section{Venture Capital Exit Mode}

At present, there are four main ways to withdraw from the venture capital, such as public listing, corporate mergers and acquisitions, corporate buy back and bankruptcy liquidation. As shown in Fig. 1.

\begin{tabular}{|c|c|c|c|}
\hline \multicolumn{2}{|c|}{$\begin{array}{l}\text { Public offering } \\
\text { - Listed on the feasibility analysis } \\
\text { Listing destination choice } \\
\text { Listed operation program }\end{array}$} & \multicolumn{2}{|c|}{$\begin{array}{l}\quad \text { Mergers and acquisitions } \\
\text { Basic form of mergers and acquisitions } \\
\text { Legal practice of mergers and } \\
\text { acquisitions } \\
\text { financial practice of mergers and } \\
\text { acquisitions }\end{array}$} \\
\hline $\begin{array}{c}\text { First } \\
\text { choice }\end{array}$ & \multicolumn{2}{|c|}{ Venture capital project } & $\begin{array}{l}\text { Second } \\
\text { choice }\end{array}$ \\
\hline & \multicolumn{2}{|c|}{ Fundamentals "selling points" } & \\
\hline $\begin{array}{l}\text { Fourth } \\
\text { choice }\end{array}$ & \multicolumn{2}{|c|}{ Market "selling points" } & $\begin{array}{l}\text { Third } \\
\text { choice }\end{array}$ \\
\hline \multicolumn{2}{|c|}{$\begin{array}{l}\text { Bankruptcy liquidation } \\
\text { - Liquidation plans and procedures } \\
\text { - Liquidation legal practice } \\
\text { - Liquidation financial practice }\end{array}$} & \multicolumn{2}{|c|}{$\begin{array}{l}\text { Enterprise repurchase } \\
\text { - Repurchase planning scheme } \\
\text { - Repurchase sales contract } \\
\text { [ Repurchase other ways }\end{array}$} \\
\hline
\end{tabular}

Fig. 1. Venture capital exit mode

A brief description of the various ways of venture capital exit is as follows [3, 4]: 
(1) Public offering. Listed is exit way with the lowest cost, highest yield and relatively short investment recovery period, it is the best way to exit the risk of investment. It makes the non-tradable shares held by the venture capitalist converted into listing Corporation stock, achieving profitability and liquidity, generally higher income, but also to maintain the independence of the company, and create a sustainable financing channels.

(2) Mergers and acquisitions. M \& A is the merger and acquisition of enterprises, and it is a main form of enterprise property right transaction. When the venture enterprise has developed to the mature stage, the enterprise has been packaged into a project by the venture capital institution, which is sold to the strategic investor to achieve the withdrawal of venture capital, access to investment income. When the venture enterprise does not have the condition of the listing, this is a better way to withdraw from the market.

(3) Enterprise repurchase. Buy-back refers to the management of the risk of enterprises or employees in cash or securities to buy back the shares have been issued outside of the corporate equity, venture capital to achieve exit, and access to investment income. This is a kind of investment withdrawal from the coexistence of advantages and disadvantages, may reduce the company's shareholders' rights and interests, affect the capital maintenance principle, and even may infringe on the interests of creditors.

(4) Bankruptcy liquidation. Liquidation exit is a kind of exit way for investment failure. For venture investors, once it is confirmed that the risk of the enterprise has lost the possibility of development and growth is too slow, and cannot achieve the expected return, a decisive exit is a wise choice, so that you can reduce the loss as much as possible, and take back the money for a new round of investment.

\section{Influence Factors on Venture Capital Exit Mode}

The influence factors of venture capital exit include two aspects: external factor and content factor, and the structure is shown in Fig. 2.

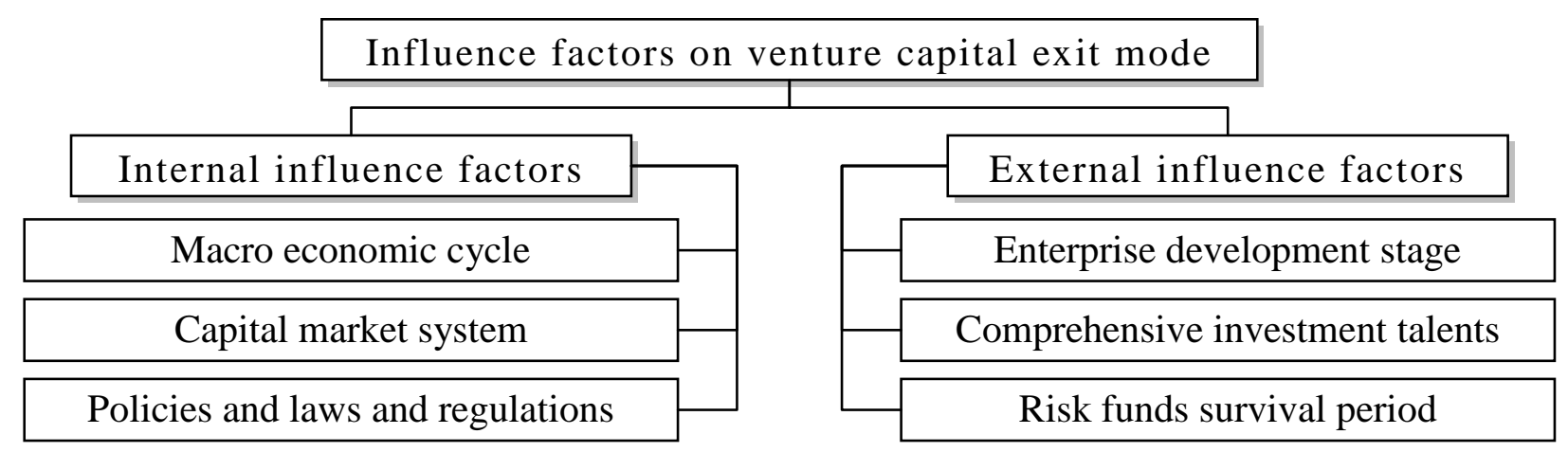

Fig. 2. Influence factors on venture capital exit mode

(1) Internal influence factors. Enterprise development stage. Enterprises in different stages of development for the demand for funds, the demand structure and the operation efficiency is different. Therefore, risk investment decision must consider the venture in what stage of development, appropriate choice of the appropriate exit; Comprehensive investment talents. Comprehensive risk investment talent is the guarantee of the development of venture capital. Venture capital requires the venture entrepreneur with the spirit of innovation and risk, and is combined with the venture capitalist who is proficient in the investment and marketing management of high and new technology, and understand the technology and the comprehensive economic management personnel; Risk funds survival period. Venture capital institutions are generally the organization of the fund, while the management of several venture capital funds, in order to maintain liquidity need to choose a reasonable investment projects and a reasonable allocation of funds due time. When the duration of a fund is in expiration and settlement, the funds will be injected into the new fund which continue to invest in circulation. Venture capital exit under the impact of time of the fund, then the fund will be terminated. Even if the risk of investment in good 
operation, the future will bring continued revenue, still need to exit. At this time in order to quickly and efficiently to achieve the exit, the risk of investment institutions will choose the way of equity transfer.

(2) External influence factors [5,6]. Macro-economic cycle. Economic cycle refers to the phenomenon that the expansion and contraction of the gross level of economic activity measured by gross domestic product. A complete economic cycle includes stages of recession, depression, recovery and prosperity. When the economy is in a boom to recession, there are more ways to sell property rights. When the economy is in a recession, the bankruptcy liquidation is more, when the economy is in a recession to recovery, property rights in the sale of the third party mergers and acquisitions will be more. When the economy is moving towards prosperity, the IPO exit will take the lead; Capital market system. The establishment of a multi-level capital market system directly affects the degree of difficulty in the exit of venture capital. If there is no exit dependent market, venture capital exit will more difficult. Multi-level capital market system is relatively perfect, and will provide more flexible trading places and ways to exit; Policies and laws and regulations. Venture capital is a complicated process, which involves a series of laws and regulations, requires a higher requirement for the legal system environment. There is no perfect laws and regulations system as a guarantee, venture capital industry will be difficult to the legalization, standardization of the road of sustainable development.

\section{Strategies on Venture Capital Exit for Science and Technology Innovation Enterprise}

Strategy refers to the plan or strategy, is a collection of achieving the goal of the program. In combination with the characteristics of science and technology innovation enterprise as well as the influence factors of venture capital exit, referring to the previous research results [7-10], the technology innovation enterprise risk investment exit strategy is put forward in this paper as shown in Fig. 3.

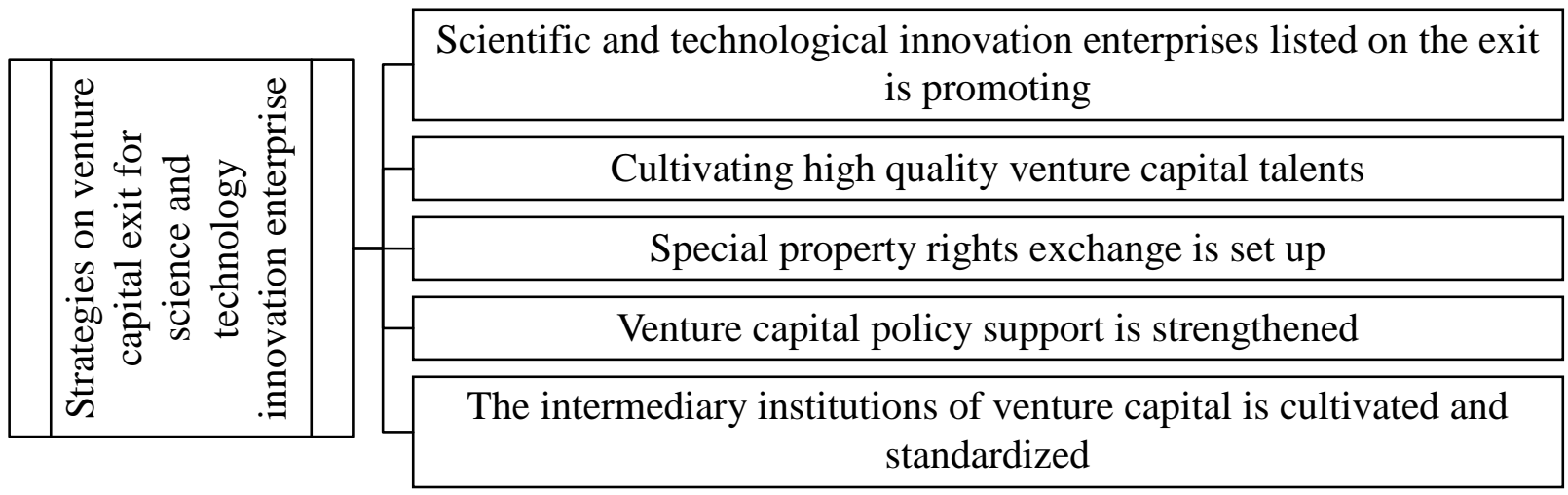

Fig. 3. Strategies on venture capital exit for science and technology innovation enterprise

(1) Scientific and technological innovation enterprises listed on the exit is promoting. Gem is different from the main board market of the securities market, designed to temporarily unable to be listed on the main board of entrepreneurial enterprises, small and medium enterprises and high-tech enterprises, such as the need for financing and development of enterprises, provide financing channels and growth space of the securities exchange market, is an important supplement to the main board market, has an important position in the capital market. Science and technology innovation enterprises listed on the exit channels should be based on the gem. In the implementation process should pay attention to the following issues: the GEM market should have a clear positioning, to avoid the motherboard; we should simplify the gem listing procedures, relax the listing standards; we should set multiple standards to meet the needs of different enterprises; we should strengthen supervision, to establish a more stringent information disclosure system.

(2) Cultivating high quality venture capital talents. Talent is the first capital of the enterprise, the competition of the market economy is finally reflected in the competition of talents. The high quality talent team is the foundation of the success of the enterprise. Venture capital requires not 
only venture capital and high technology, but also need to be familiar with the operation of the market, have the experience of operating and management, be good at capturing market information and can control the risk of investment experts to organize investment. To make great efforts to cultivate and the introduction of a number of has the risk consciousness and market consciousness, with pioneering and enterprising spirit of the high-quality comprehensive talents of risk investment, and actively promote the development of innovation of science and technology of China venture capital industry.

(3) Special property rights exchange is set up. It is a very important way to realize the venture capital exit of science and technology innovation enterprise through the property right transaction. We should formulate relevant policies and regulations, standardize and promote the combination of venture capital and capital market, and reduce the cost of the combination of venture capital and capital market. We can select some high credibility and high management level of Securities Company took the lead in carrying out the counter transactions in scientific and technological innovation of enterprises are concentrated area, according to the market mechanism acting sale risk investment enterprises property rights, eventually for the enterprise technological innovation to design special property right trading venues. While introduce new trading varieties, we innovative trading system, in order to enhance the adaptability of the external environment changes in the property market.

(4) Venture capital policy support is strengthened. The main function of the government is to facilitate the development of venture capital, and guide the development of private venture capital institutions. In order to encourage scientific and technological innovation enterprise development, the state should increase the intensity of preferential policies for science and technology innovation enterprises, to extend the tax exemption period, to further reduce the enterprise income tax rate. At the same time, by way of booking increases purchasing new products of the enterprise technology innovation, for risk investment in scientific and technological innovation projects to provide financing services, and provide information consultation for high technology products upgrading. When the losses incurred in the enterprise technology innovation risk investment projects, we can use the losses of risk investment funds directly offset fund other sources of income payable income tax.

(5) The intermediary institutions of venture capital is cultivated and standardized. In the development of venture capital of science and technology innovation enterprise, the intermediary service system is an indispensable part. Science and technology innovation enterprise venture capital factors, including investors, venture capitalists, venture entrepreneurs, intermediary service system and the relevant government departments. The role of intermediary service agencies is mainly through the service means and financial tools to create the relevant elements of the object, some of the main elements of the organic communication and connection, to better serve the other elements of the main body. The establishment of the elimination system, for not to speak good faith, not to guard against professional ethics and have serious violations of laws and regulations of institutions and practitioners, to clear out the industry, and to limit its reentry.

\section{Conclusion}

Science and technology innovation enterprise is a country's most dynamic enterprise, is the main force of the construction of innovative country, is the focus of the government's target, but also the investment object of venture capital institutions. To promote the rapid development of science and technology innovation, venture capital is an important force, if you cannot let the risk of investors get income, it will blow the enthusiasm of investors, which is not conducive to the investment behavior of venture investors. The innovation of science and technology of China venture capital exit, there exist a lot of problems. IPO strict conditions and high cost, enterprise merger and acquisition of the property rights trading market is underdeveloped, corporate repurchase operations are not standardized and smaller, overseas listing exist between countries legal system and cultural differences, the bankruptcy liquidation is a failed investment upset. The research results of this paper provide a strategy to solve these problems, and enrich the research content of venture capital, 
which is of great significance to promote the development of venture investment in scientific and technological innovation enterprises.

\section{References}

[1] Y. X. Zhang, L. L. Zhao, "Government support and financial development, social capital and the financing efficiency of S\&T innovation enterprises," Science Research Management, vol. 36, no. 11, pp. 55-63, 2015.

[2] W. L. Jiang, "Research on Strategy Selection and Equity Auction Mechanism in Venture Capital Exit," Doctor's Degree of Wuhan University, 2013.

[3] M. B. Lu, "The Research of Exit Mechanism of High-tech Enterprise of Venture Capital," Master's Degree of Xiangtan University, 2010.

[4] Baidu Knows, "What are the ways of venture capital exit," http://zhidao.baidu.com/link?url=Y9U0C02MGdsxvzk4niFdoxt1M-W49tc5FI_1r9yIuO_rYow FO92BgK2wltzA18DmlsRL4mcqUb9dSv2u_o22yTt8OEiBZs-ycdw3JRx4iTC, 2016-5-15.

[5] L. J. Wang, , "Analysis on the exit mode of venture capital in China and its influencing factors," China Economist, vol. 30, no. 7, pp. 47-47, 2015.

[6] S. R. Lv, H. Y. Pei, "Factor-analysis of impacting choice of venture capital exiting means," Journal of Hebei University of Science and Technology (Social Sciences), vol. 8, no. 1, pp. 6-10, 2008.

[7] T. T. Xiang, "High tech industry, financial development and venture capital investment," Times Finance, vol. 36, no. 7, pp. 99-100, 2016.

[8] L. G. Liu, , "Research on exit mechanism of venture capital investment," Commercial Accounting, vol. 37, no. 5, pp. 48-52, 2016.

[9] Y. Y. Zhao, "Venture capital exit mechanism with Chinese characteristics under the new normal state," Modern Enterprise, vol. 35, no. 1, pp. 37-38, 2016.

[10] Q. Wang, "Thoughts on the exit mechanism of venture capital in China," Modern Business, vol. 11, no. 7, pp. 99-100, 2016. 